\title{
The Development of Surga Beach Tourism Potential in East Lombok Regency
}

\author{
* Auliana Emra ${ }^{1)}, \mathrm{Zul} \mathrm{Amri}^{2)}$, and Indang Dewata ${ }^{3)}$
}

1) Master Program Student of Geography Education Faculty of Social Science, Universitas Negeri Padang, INDONESIA

2) Department of English, Universitas Negeri Padang, INDONESIA

3) Department of Environmental Science, Universitas Negeri Padang, INDONESIA

Email: aulianaemra6@gmail.com

*Corresponding Author, Received: February 17, 2018, Revised: April 25, 2018, Accepted: May 24, 2018

\begin{abstract}
This research attempted to study about the development of tourism potential in East Lombok Regency (object: Surga Beach). It adopted a descriptive qualitative research design. The data was in the form of qualitative data and collected through interview. The result explained about the development of the potential and its inhibiting factors in East Lombok Regency. With surga Beach's contribution to Locally-Generated Revenue (PAD) and better regional autonomy, East Lombok still had many problems in developing the tourism potential. The development is hoped to give a positive impact to tourism in Indonesia in general and tourism in Lombok in particular that government, local people and private parties should pay greater attention to it.
\end{abstract}

Keywords: The Development of Tourism Potential, Tourism, Surga Beach

\section{Introduction}

Tourism has become one of prima donna to countries to increase their revenue other than of oil and gas and taxes. Today Indonesia as one of developing countries starts promoting the country in order to attract world's attention. It is aimed to introduce Indonesia to foreigners so they want to visit Indonesia. The promotion includes marketing the diverstity of Indonesian culture and tourism and this has a positive feedback which is shown by the increase number of foreign tourists that come to Indonesia.

According to Rani (2014) Indonesia has various culture and tourism that can help solving its fundamental problems through economic strengthening of its foreign exchange earnings and regional income. Therefore, Indonesia can develop its potentials, in this case its tourism, because the toursits that come to Indonesia mostly aim to seek for and enjoy Indonesia natural beauty. It will produce domino effect both for domestic and foreign. If Indonesia is getting famous at other countries, it can increase the foreign exchange and national welfare. Gunardi (2010) stated that tourism has a big role in national development because other than generating revenue and foreign exchange it significantly relates to foreign investment. Foreign visitors of Indonesia also include the ones who want to do business with Indonesia. Then, Soedarso et al., (2014) said that tourism business is an activity whose purpose is to organize travel services or provide or offer tourist attraction, tourism products (goods) and other related business. 
Another definition comes from Suamadi and Sidauruk (2011) who define tourism industry as an organization, governmental and private, whose development, production and product marketing are aimed to meet tourists demand. There are many tourism potentials in Indonesia. If government and local people want to cooperate in developing the potentials, the tourism can improve local economy, culture and education. Tourism is very able to solve welfare related problems if it is professionally developed. In its development not only government itself but also other related parties take part in the development of supporting infrastructure which aims to improve tourism economy sector. Hidayat (2011); Hermon (2012); Hermon (2014) explained in his book, the steps of toursim development planning are started with the development of regional tourism including physical development of the attraction. From that, tourists number that visit the place can be observed and if it meets the target number, the next step will be deciding the priority system. To do so, there is a need for approaches to available tourism organizations (government and private) and related parties who are hoped to be able to support the continuity of the regional tourism development.

In addition, Rusita et al., (2016); Hermon (2009) opined that a regional development can be adapted by local government to local uniqueness and potentials. This is an excellent opportunity for the government to show off their abilty in exercising its authority to establish right for the region. Progression and regression of a region is strongly determined by local government's ability and willingness to carry out the development. They are free to be creative and expressive in developing its region and of course without violating the rule of law.

\section{Method}

This study employed a descriptive qualitative research design. The focus of this research was the people that involved in tourism development (Surga Beach) in East Lombok Regency. It studied the developement of tourism in Surga Beach together with its inhibiting factors and strategies to solve those problems. It was set in East Lombok Regency precisely at Surga Beach. The research data was obtained by conducting observation and deep interview. Then, the researcher suggested a number of strategies that are considered able to solve the problem. Those strategies were obtained from SWOT analysis by formulating internal (strength and weakness) and external (opportunity and threat) factors of Surga Beach attraction (Hermon, 2017).

\section{Results and Discussion}

According to Devy and Soemanto (2017), tourism is a complex activity which can be see as a big system consisting of various components of economy, politics, social, culture and others. To see tourism as a system means to analyze it from various persectives like politics, economy, culture and so forth and their interconnectedness. As a system, an interdependency relation between components is created wherein the change of one subsystem will cause the change of other subsystems until a new harmony is found. There are many actors that involve in and move the tourism system. Those actors are from various sectors. According to Dewa and Sunartaa (2015:71), tourism actors are generally classified into three main groups, they are (1) society, (2) private, (3) government. Society includes general public in the destination who are the owners of various resources that are considered as tourism assets, for example culture. It also includes community leaders, intellectuals, NGOs and mass media. Then, private covers tourism business association and businessmen while government group covers all administrative areas including governments in central, province, regency, district and so forth. The tourism system will be well organized if all those components (actors) are merged into one and support each other. For example, a local government must jointly plan, develop, organize, maintain and supervise with other local governments of all sectors who support tourism activities (Primadany et al., 2007).

In the development of tourism potentials in East Lombok, there were many factors that might affect the success and failure of the development. East Lombok has many tourism potentials including natural tourism, religious tourism, and historical tourism. Until today, the government of East Lombok has been doing 
promotion to introduce its tourism that the number of tourists is effectively increasing every year eventhough it is not widely known by all people. The government has also been developing the tourism so that visitors can enjoy the natural beauty of East Lombok. Through tourism promotion and development, the government can increase local revenue. For the development, government also cooperate with media to display the tourism in East Lombok especially on its anniversary when various tourism activities take a place. The development has a main focus on infrastructure development and promotion activities in order to attract domestic and foreign tourists.

Based on the data obtained from Office of Culture, Tourism, Youth and Sport (hereinafter referred to as DISBUDPARPORA), the number of tourists had been increasing every month and every year. Tourism potential in East Lombok is quite a lot. It can be seen from its geographical condition which offers many tourist attactions like religious tour, beach tour, and culinary tour. Of those tourist attractions in East Lombok, a very prominent one is religious tourism. This rapid development significantly affected local people due to an increase of tourists that come to East Lombok. This was because there was a balance between government's and local people's role in exploiting available potentials. Today's development of tourism potential also influences the implementation of regional autonomy. East Lombok has ben well implementing its autonomy and this is shown by its success in increasing locally-generated revenue (PAD) because the success of an autonomy is determined by the regional revenue. Other than national contribution, the tourism development in East Lombok also contributed to the development of East Lombok itself. This could be seen from how the local government coordinated all official services to help developing the local tourism. The coordination allowed DISBUDPARPORA to achieve their goals.

A quite number of tourism in East Lombok can generally affect the society beucase it will create a balance between the roles of government, local people and other related parties in its development. The development by regional government also involves an extensive tourism development which results in a positive effect for local government and local people. Tourism development in East Lombok is one of central government programs in promoting tourism to investors and foreign tourists to visit Indonesia because so far tourism sector in Indonesia is still very much in comparison to the neighboring countries' like Singapore and Malaysia. That is why Indonesia has been promoting its tourism to compete globally. Moreover, although the development of tourism in East Lombok has given a positive effect, the problem in its development can not be ignored.

Wijayanto et al., (2009) argued that tourism development causes a higher local revenue. As explained by the chief of DISBUDPARPORA, PAD earned by tourism sector reached to $200 \%$ and this means that government has been successful in independently fulfilling the needs of the region.This increase will be the source for government to fulfill its need and motivate other regions to do the best in exercising their authorities to fulfill their needs (Central Bureau of Statistics of East Lombok Regency, 2017). The achieved PAD enables the region to realize its people welfare. The development of tourism is not only done by East Lombok but also by other regions in order to strengthen national foreign exchange in tourism sector because to date Indonesia's country income has been depending on income from taxes. So, it is time for tourism in Indonesia to play a major role since developed countries have already relied on tourism sector as their main incessantly national income source.

However, tourism development in Indonesia faces many problems. There are many regions that are unable to well manage their tourism, so does East Lombok Regency. Some local people had not been able to open with the development. The problem was also of infrastructure. The infrastructure in East Lombok had not yet support the development of tourism. It was caused by government's limited support of infrastructure such as the roads leading to the attraction that were mostly damaged and lack of lighting along the roads. This condition made tourists uncomfortable and reluctant to visit the place. Moreover, there was only limited transprotation that pass through tourism attractions in East Lombok especially the ones that went to beach attraction, in this case Surga Beach. So, if tourists want to visit the place they should rent vehicles and this will be burdensome. Those are problems faced by managers or governments in optimally managing and developing the tourism in East Lombok.

Tourism development should be highly supported by not only governments and related parties but also tourists and local people in general as explained before so the tourism in East Lombok can be more attractive to invite people visit the place. The mentioned problem can gradually be solved along annual 
program improvement and achieved goals. The synergy between local people will has a great impact because they are the spearhead in tourism development. Therefore, they should be accompanied by government so that they can be taught and trained on how to develop the tourism in East Lombok.

The purpose of tourism development of Surga Beach is to create public welfare around the beach and a better and equitable standard of living. People's standard of living is determined by the capability of internal and external factor. Internal factor is generated from social influence which leads to inequality that can not significantly increase public welfare because there is discrepancy between one resident and the others. Meanwhile, external factor is the result of other parties' involvement which makes socio-economy of the region not being able to icrease (Hepi et al., 2015).

Local people in the beach area and the Technical Implementation Unit (UPT) were cooperating in improving the quality of the place. They jointly organize events for promoting tourist attraction in East Lombok especially its remarkable natural tourism, in this case Surga Beach that is very attractive to visit and surrounded by its natural wealth. To date, government of East Lombok has been developing the tourism potential which is considered able to compete with tourism in other regions in order to welcome ASEAN free market which involves tourism sector as one of media. In order to develop Surga Beach, East Lombok has designed development strategies although most of those strategies have not yet been practiced in the development. Government, private sector and local people cooperate in the development of Surga Beach by using strategies such as promoting the site, community activities (touring), and improvement of supporting infrastructure and facilities.

Surga Beach is a tourism in East Lombok that has many natural beauties. Following the development of tourism in Indonesia, Surga Beach should also be improved. If it is well developed, East Lombok along with its tourism will indirectly improve the economy and standard of living of the people involved in its development. Despite its natural wealth, Surga Beach is still lagging far behind. In these past few years, government's strategies have been effective because every year Surga Beach has given great contribution to East Lombok PAD. By the support of involved parties, Surga Beach will be one of tourist's main destination because it offers various uniqueness.

Local government of East Lombok is also given opportunity for promoting and developing the place. With good supervision and management, Surga Beach will progress in tourism sector of East Lombok. Therefore, local government should be able to propose a new insight to local people who live around the beach area and create decent welfare for them. This research found that the local people still could not accept the idea of beach tourism development due to the classic reason of "destroying existing culture". Religious culture of East Lombok will be diminished if foreign culture is imported without filtration. So, government of East Lombok, private parties and local people of Surga Beach should have same idea if they want the development to increase. Based on those internal and external factors found in Surga Beach destination, they can be formulated into strategies by using SWOT analysis. These strategies are hoped to be useful for the development planning and program of Surga Beach tourism in East Lombok. 
Table 1. The Formulation of Strategy in SWOT Analysis

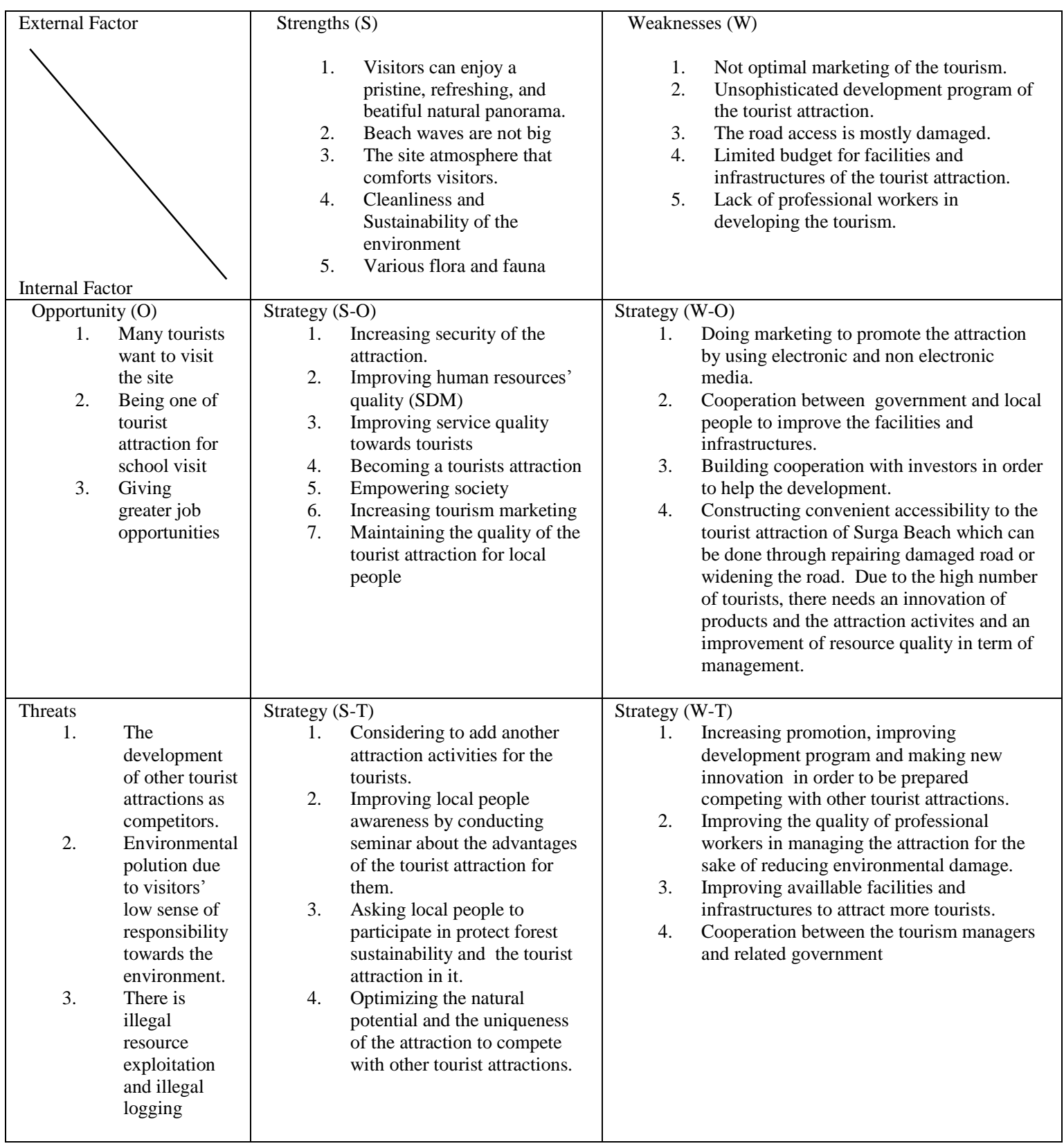

\section{Conclusion}

The government of East Lombok Regency had been gradually developing available tourism potentials, East Lombok's culture and economy. They were able to support the tourism that effectively had an impact on a high increase of local income in tourism sector. However, as for the people of East Lombok they did not yet get significant advantage of tourism development. Another problem was government's limitation of budget allocation due to geographical factors of East Lombok which is located at the end of island. In other words, the budget of local government did not meet the development needs so the development would take a quite long time. Moreover, there was also cultural or traditional limitation. In term of infrastructure, the problem was that it still could not support the tourism development in East Lombok because government had not optimally 
provide the infrastructure. It could be seen from the road condition that was greatly damaged and the limited lighting along the road that tourists were uncomfortable and reluctant to visit the place. This later results in a decrease of tourist numbers that visit Surga Beach in East Lombok.

\section{References}

Rani, D.P.M. (2014). Pengembangan Potensi Pariwisata Kabupaten Sumenep, Madura, Jawa Timur (Studi Kasus: Pantai Lombang). Mahasiswi S 1 Program Studi Ilmu Politik, FISIP, Universitas Airlangga. Jurnal Politik Muda, Vol. 3 No. 3, Agustus-Desember 2014, 412-421.

Dewa dan Sunarta. (2015). Studi Pengembangan Desa Pinge Sebagai Daya Tarik Ekowisata Di Kecamatan Marga Kabupaten Tabanan. Program Studi S1 Destinasi Pariwisata, Fakultas Pariwisata,Universitas Udayana. Jurnal Destinasi Pariwisata Vol. 3 No 1, 2015.

Gunardi. G. (2010). Identifikasi Potensi Kawasan Wisata Kali Pasir, Kota Tangerang. Jurusan Teknik Planologi - Universitas Esa Unggul, Jakarta. Jurnal Planesatm Vo. 28 1, No. 1, Mei 2010.

Devy, H dan Soemanto. (2017). Pengembangan Obyek Dan Daya Tarik Wisata Alam Sebagai Daerah Tujuan Wisata Di Kabupaten Karanganyar(Studi Kasus Obyek Wisata Air Terjun Jumog di Kawasan Wisata Desa Berjo, Kecamatan Ngargoyoso, Kabupaten Karanganyar). Program Studi Sosiologi, Fakultas Ilmu Sosial dan Politik, Universitas Sebelas Maret, Surakarta. Jurnal Sosiologi DILEMA, Vol. 32, No. 1 Tahun 2017.

Hermon, D. (2009). Dinamika Permukiman dan Arahan Kebijakan Pengembangan Permukiman pada Kawasan Longsor di Kota Padang. Disertasi. IPB Bogor

Hermon, D. (2012). Mitigasi Bencana Hidrometeorologi: Banjir, Longsor, Degradasi Lahan, Ekologi, Kekeringan, dan Puting Beliung. UNP Press.

Hermon, D. (2014). Geografi Bencana Alam. Radjawali Press.

Hepi, I.M. (2015). Analisis Pengembangan Wisata Pantai Indah Popoh Sebagai Daerah Tujuan Wisata Kabupaten Tulungagung. Fakultas Ilmu Administrasi Universitas Brawijaya. Jurnal Administrasi Bisnis (JAB)|Vol. 26 No. 2 September 2015.

Wijayanto, I.H. et al., (2004). Pengembangan Potensi Pariwisata Dalam Perspektif Reinventing Government (Studi Di Dinas Kebudayan Dan Pariwisata Kabupaten Lamongan). Jurusan Administrasi Publik, Fakultas Ilmu Administrasi, Universitas Brawijaya, Malang. Jurnal Administrasi Publik (JAP), Vol. 1, No. 6, Hal. 1168-1173.

Hidayat, M. (2011). Strategi Perencanaan Dan Pengembangan Objek Wisata (Studi Kasus Pantai Pangandaran Kabupaten Ciamis Jawa Barat). Politeknik Negeri Bandung. Tourism and Hospitality Essentials (THE) Journal, Vol. I, No. 1, 2011 - 33.

Rusita et al. (2016). Studi Potensi Objek Dan Daya Tarik Wisata Alam Air Terjun Wiyono Di Taman Hutan Raya Wan Abdul Rahman, Provinsi Lampung. Dosen Jurusan Kehutanan Fakultas Pertanian Universitas Lampung. Info Teknik Volume 17 No. 2 Desember 2016 (165-186).

Primadany, S.R. et al. (2007). Analisis Strategi Pengembangan Pariwisata Daerah (Studi Pada Dinas Kebudayaan Dan Pariwisata Daerah Kabupaten Nganjuk. Jurusan Administrasi Publik, Fakultas Ilmu Administrasi, Universitas Brawijaya, Malang. Jurnal Administrasi Publik (JAP), Vol. 1, No. 4, Hal. 135-143.

Soedarso et al. (2014). Potensi Dan Kendala Pengembangan Pariwisata Berbasis Kekayaan Alam Dengan Pendekatan Marketing Places(Studi Kasus Pengembangan Pariwisata Di Kabupaten Bojonegoro). jsh Jurnal Sosial Humaniora, Vol 7 No.2, November 2014.

Suamadi dan T. Sidauruk. (2011). Kajian Potensi Wisata Air Terjun Ponot Di Desa Tangga Kecamatan Aek Songsongan Kabupaten Asahan. Jurusan Pendidikan Geografi Fakultas Ilmu Sosial Universitas Negeri Medan.Jurna; Geografi Vol 5. No.1 - 2013. 